\title{
FLAMENCO-KITARANSOITTO JA KAPPALELAJIT
}

Flamenco on Etelä-Espanjassa, Andalusiassa syntynyt kansantaiteen laji, johon kuuluvat laulu, tanssi, kitaransoitto ja rytmiset kättentaputukset. Oma alueensa on lisäksi laululyriikka, jonka tunnetuin edustaja lienee Frederico Garcia Lorca. Flamenco on alunperin Andalusian mustalaisten taidetta, joka on saanut toisaalta arabialaisia ja toisaalta eurooppalaisia vaikutteita. Tutkimuksissa on havaittu myös intialaisia vaikutteita, koska mustalaiset ovat lähtöisin Intiasta sekä juutalaisia vaikutteita. Flamencon ilmaisuvoimaan ovat sittemmin ihastuneet myös ei-mustalaiset taiteilijat, ja varsin yllättävänä seikkana voi mainita, että esimerkiksi Suomessa on useita satoja flamenco-tanssin harrastajia ja useita kymmeniä soittajia. Tässä laajuudessa flamencon leviäminen Suomeen on tapahtunut noin viiden vuoden sisällä.

Flamenco-tyylin kehityksessä esiintyy sama mustalaismusiikille tyypillinen ilmiö, mikä on havaittavissa muuallakin Euroopassa: mustalaiset sulauttavat valtakulttuurin musiikista tiettyjä piirteitä omaan musiikkiinsa ja yhdistelevät näin eri elementtejä. Eräät tutkijat ovat tulkinneet tämän merkitsevän sitä, ettei mustalaisilla olisi omaa luovuutta musiikin suhteen. Toisaalta olisikohan olemassa montaakaan musiikkikulttuuria, joka olisi syntynyt tyhjästä, täysin ilman vaikutteita ja perinteitä? 
Flamenco on mustalaisten vainojen keskellä ollut tärkeässä osassa psyykkisenä purkautumiskeinona. Se onkin ollut sorretun väestönosan musiikkia, ja tästä syystä flamencossa on aina läsnä jotenkin traaginen tunnelma. Siinä on hyvin itämainen sävy, joka muistuttaa muhammettilaista rukouslaulua. Laulussa on paljon liukuja, mikrointervalleja ja koloratuureja ja sen äänenväri on nasaali ja käheä yhtä aikaa. Laulua pidetäänkin flamencon perustana. Kitaransoitto taas on kehittynyt flamencon kiinteäksi osaksi varsin myöhään, tällä vuosisadalla. Syy on ollut kitaroiden kalliina pidetty hinta. Ennen kitaraa - viime vuosisadalla - on tavallisesti isketty kepillä tahtia lattiaan ja laulettu ja taputettu käsillä tämän rytmin päälle. Myös tanssi on vanhaa perua. Se mainitaan jo ensimmäisissä kirjallisissa dokumenteissä.

Flamenco-tanssissa on paljon itämaisia piirteitä. Käsien ja sormien pyöritys muistuttaa intialaisessa tanssissa ilmeneviä liikkeitä, samoin jalkojen koputukset. Koputuksilla luodaankin erilaisia ääniä riippuen siitä, käytetäänkö koko jalkaa, kengän kantaa vaiko kengän kärkeä tai sitten päkiää. Näiden tekniikkojen valikoimalla tanssija voi luoda melkein yhtä rikkaan rytmikudelman kuin rummuilla, lautasia lukuunottamatta. Tanssin kannalta keskeinen käsite on kontratiempo, joka tarkoittaa sitä, että tanssija luo vastarytmin kitarasäestykselle tai päinvastoin. Flamencossa onkin tavallista että rytmilliset taukopaikat pyritään täyttämään yllättävillä iskuilla.

Kitaransoiton harmoniaa tutkimalla löytyy arabialainen vaikutus tästäkin osatekijästä. Arabialainen hidjaz-asteikko löytyy flamencosoinnutuksesta. Eräät kitaransoittotavat muistuttavat ud-luutun soittotapoja. Kitaransoitossa esiintyvät legato-koristelut muistuttavat paitsi laulun itämaisia koloratuureja, myös itämaisten kielisoittimien ( $u d$ ja tar) soittotapoja. Kitaransoitto on alunperin ollut yksinkertaista rasqueo-tekniikalla tapahtuvaa rummutusta. Klassinen kitaransoitto on vaikuttanut flamenconsoittoon ja päinvastoin. Nykyään flamenconsoitto on virtuoosisuudessaan erittäin pitkällä (esim. Paco de Lucia). Flamencon itämaiset sävyt ovat osittain peräisin ajalta, jolloin Etelä-Espanja oli maurilaisvallan alaisuudessa. 


\section{Kitaransoitto}

\section{Tekniikka}

Flamencossa kitaransoiton tekniikka on tällä vuosisadalla käynyt läpi voimakkaan kehitysprosessin. Vielä vuosisadan alussa cante jondo eli flamencolaulu tarkoitti samaa kuin flamenco. Kitaransoittotyyli käsitti muutamia sointuja, joita soitettiin rasqueo- ja yksinkertaisilla picadoteknikoilla ( Pohren 1972, 71-72).

Flamencossa soittotekniikka on kehittynyt erityisesti musiikin tyylillisten seikkojen sanelemana. Kitarasäestyksessä musiikin rytmillistä puolta korostavat rasqueot ja golpe-iskut. Rasqueo-tekniikka on flamencon rytmillisen luonteen vuoksi hyvin integroitunut kokonaisilmaisuun, koska flamencossa rytmilliset fraasit alkavat usein kohotahdilla ja päättyvät iskuun, usein vielä fraasin viimeiseen iskuun. Rasqueo-tekniikka on tehokas keino tuoda esille kohofraaseja. Nämä tekniikat tuottavat voimakkaita aksentteja, joita tarvitaan muuten hentoäänisen kitaran esilletuomiseksi, varsinkin jaksoissa, joissa esiintyy kättentaputuksia. Rasqueo- ja golpe-tekniikat eivät kumpainenkaan kuulu klassisen kitaransoiton piiriin, moderneja sävellyksiä lukuunottamatta.

Yleiseen kuulokuvaan flamenconsoitossa vaikuttaa myös äänenväri, joka on kireä ja nasaali - samaan tapaan kuin laulun ääni-ideaali. Tämä seikka on yleinen eri musiikkikulttuureissa; soitossa jäljitellään laulun äänenväriä (Nettl 1973, 19). Lisäksi nasaali ääni-ideaali on yleinen panislamilaisen kulttuurin piirissä, jota Andalusian aluekin on edustanut lähes seitsemän vuosisataa. Kitaransoiton falseta-jaksoissa tavataan myös yhtäläisyyttä laulutyyliin. Pitkät ornamenttijaksot ovat melodisen liikkeen ja tyylinsä puolesta lähellä laulua. Korukuviointi on flamencon kitaransoittotyylissä lähellä panislamilaisessa musiikkikulttuurissa tavattavia soittotekniikoita.

Klassisen kitaransoiton kanssa yhteisiä tekniikoita ovat näppäily- 1. picado-tekniikka, arpeggio- ja tremolotekniikat.

Rasqueo. Tämä on flamenconsoitossa tyypillinen tekniikka, jossa eräänlainen harjaava efekti tuotetaan soittamalla kieliä oikean käden sormilla ulospäin - oikaisten sormet perättäisenä sarjana. Rasqueo-tekniikasta on olemassa hyvin erilaisia sovelluksia. Yksinkertaisimmassa muodossa soitetaan sävelet alkaen nimettömästä päätyen etusormeen, jolloin muodostuu kolmisävelinen rasqueo. Monimutkaisemmissa tyypeissä saatetaan toistaa 
esim. viisi-iskuista rasqueota sarjana, kuten seuraavassa (Pena 1976, 12).

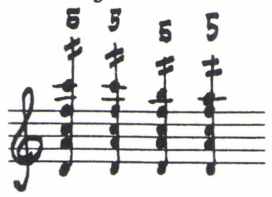

Rasqueolla on usein kohoiskun luonne, mikä soveltuu flamencon luonteenomaiselle piirteelle korostaa tiettyjä iskuja. Rasqueon ansiosta nämä iskut saavat lisää painokkuutta. Tämän vuoksi on hämmentävää, kuten usein näkee tehtävän, käyttää pelkkää murtoviivaa rasqueon osoittamiseksi. Toisaalta on miltei mahdoton soittaa flamencoa ilman kuultua kontekstia. Esimerkiksi rasqueo, joka kirjoitetaan

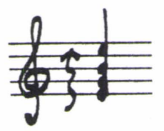

(Pena 1976, 5) ei tarkoita, että ensimmäinen soitettu sävel olisi juuri mainitulla 1/4-iskulla, vaan sävelet soitetaan etusävelinä, joiden paino tähtää pääiskulle. Täten edellisellä tavalla kirjoitettu rasqueo on soitettava:

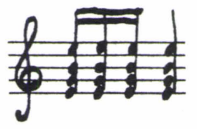

Erikoinen rasqueo-tekniikka on ns. triple 1. kolmi-iskuinen rasqueo. Tällä tekniikalla tuotetaan pitkä rullaava efekti, joka muistuttaa tremoloa.

1. Peukalo soittaa voimakkaan ylöspäisen näppäyksen kaikilla kielillä.

2. Keskisormella näpätään alaspäin .

3. Peukalo näppää kaikilla kielillä alaspäin. (Martin 1978, 84)

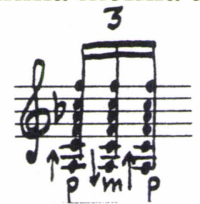

Rasqueon voima tulee tässä tekniikassa peukalon ja keskisormen näppäyksistä yhdistettyinä ranteen liikkeeseen(ibid, 84-85).

Golpe. Tämä tarkoittaa tiettyä flamenconsoitolle ominaista tekniikkaa, jossa sormella ja sen kynnellä näpäytetään kitaran kanteen tai erityisesti tarkoitusta varten laitettuun suojukseeen, golpeadoriin. Useimmiten golpe tehdään nimettömälllä sormella, ja se voidaan soittaa samanaikaisesti tai eriaikaisesti soinnun tai yksittäisen sävelen kanssa. Golpe-tekniikalla on rumpumainen vaikutus, ja se soveltuu erinomaisesti korostamaan rytmisiä poikkeamia. 
rumpumainen vaikutus, ja se soveltuu erinomaisesti korostamaan rytmisiä poikkeamia.

Golpella on tärkeä merkitys siirtymäjaksoissa. Esimerkiksi solearesissa voidaan ajatella 11. ja 12. iskun olevan silta kahden fraasin välillä . Tämä lopuke eli cierre voidaan yhdistää edeltävään tai seuraavaan falsetaan, mutta yhteinen tekijä lopukkeilla on golpe, joka näpäytetään kitaran kanteen 12. iskulla. Vaikka cierren kaksi tahtiosaa ovat huomaamattomia, on toisella iskulla oleva golpe merkittävässä asemassa, sillä se yhdistää kaksi falsetaa yhteen. Sen ajoittaminen tarkasti on erittäin tärkeää, sillä väärä ajoitus tuhoaa falsetat molemmilla puolilla. Golpen ei tarvitse olla kovin voimakas, mutta kylläkin terävä. Golpen terävöittämiseksi on hyödyllistä sammuttaa soivat kielet. ( Davies 1985, 25)

Golpe on tärkeässä asemassa myös llamadassa eli kutsussa, joka on laulajalle aloitusmerkkinä. Tässä llamadassa fraasin ensimmäinen, toinen ja kolmas isku ovat yksinkertaisia ja cierrestä puuttuvat melodiasävelet.

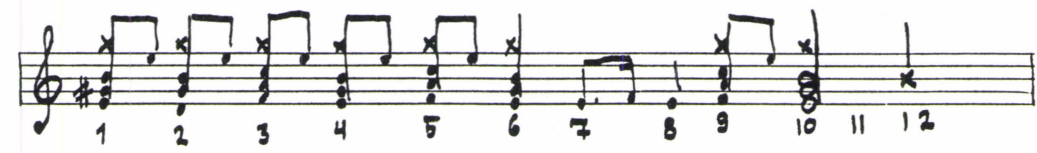

Toisenlainen "llamada", jossa ketään ei kutsuta jatkamaan on seuravanlainen. Siinä ei käytetä cierren toisella osalla golpea. Jos golpe sisällytettäisiin, aloittaisi laulaja kuten edellisessä esimerkissä. Laulaja tunnistaa llamadan ensimmäisen, toisen ja kolmannen iskun aikana, compasin lopun 10. iskulla, tauon cierren 1 . iskulla ja cierren 2 . iskulla hän vetää henkeä aloittaakseen seuraavan säkeistön 1. iskulla. Kokenut ammattilainen on ehdollistunut tekemään niin ja hänen on hyvin vaikea olla tekemättä niin. Llamadan on oltava selvä, koska kitaristin, laulajan ja palmeroksen on tiedettävä jatketaanko, lopetetaanko 10. iskulla vai lauletaanko. Tempon variointi on tehtävä myös selväksi cierren aikana. Ammattilaisten ei tarvitse harjoitella keskenään, koska informaatio sisältyy tanssiin tai musiikkiin itseensä.

Tremolo.Tämä tekniikka on flamenconsoitossa toisinaan samanlainen kuin klassisessa kitaransoitossa, jolloin sormijärjestys on p.,a.,m.,i., mutta flamencossa tavallinen on myös viisisävelinen tremolo, jolloin järjestys on p.,i.,a.,m.,i. Tremolossa peukalo soittaa basso- ja sointusäveliä ja muut sormet soittavat jotain diskanttisäveltä( Pena 1976, 15 ).

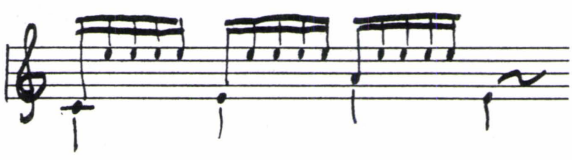


Tremoloa käytetään falsetajaksoissa, eikä niinkään säestysjaksoissa, koska äänenvoimakkuus ei tässä tekniikassa yllä laulun tai tanssijan koputusten tasolle. Useissa yhteyksissä tapaa väitettävän, että tremolon olisi ensimmäisenä omaksunut klassisen kitaransoiton vaikutuksesta Ramon Montoya, ja että hän olisi lanseerannut tämän tekniikan flamencon piiriin $(\mathrm{Ba}-$ tista 1972, 9). Jos tremolossa on käytössä useita kieliä, sormet liukuvat yksi kerrallaan kaikkien tremolossa käytettävien kielten yli. Tällaista tremoloa käyttää mm. Manitas de Plata.

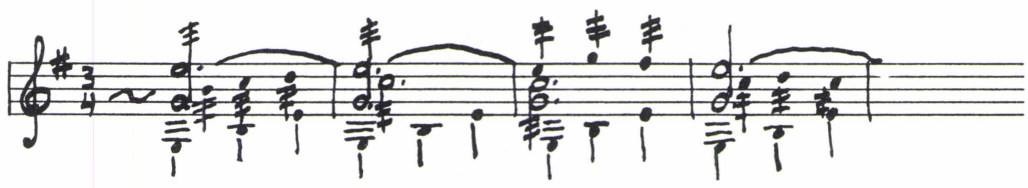

Apagado. Katkaistakseen kielten soinnin yhtäkkisesti flamencokitaristi käyttää tekniikkaa, jota kutsutaan nimellä apagado, so. vaiennettu. Tämä saadaan aikaan joko oikean käden kämmensyrjällä tai vasemman käden pikkusormella. Oikean käden apagadossa kämmen palautetaan terävästi takaisin kielille lyönnin jälkeen. Kämmensyrjä sammuttaa kielet nopeasti (Martin 1978, 70).

Vasemman käden apagadossa pikkusormi sammuttaa kielet sen jälkeen kun oikea käsi on näpännyt niitä. Pikkusormi painaa kevyesti kaikkia kieliä juuri sen verran, että kielten värähtely estyy - kieliä ei siis paineta kiinni otelautaan. Oikean käden tekniikka on näistä kahdesta tehokkaampi, mutta vasemman käden tekniikalla voidaan sointustaccatoja tuottaa nopeassa sarjassa.

Apagado on flamencon rytmisen iskevyyden ja sykkeen kannalta tehokas tekniikka, koska sillä saadaan tauot rajattua hyvin selvästi. Taukojen sijoittaminen aksenttien lomaan lisää rytmin vaikuttavuutta (de Plata 1976, 19).

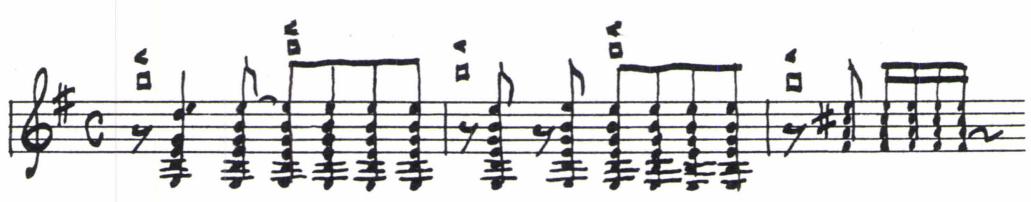

Alzapua. Nimi alzapua tulee sanoista alzar (nostaa) ja pua (näppäin). Tämä on spesifinen flamenco-tekniikka, joka luo voimakkaan rytmisen pulssin melodiajaksoihin.Alzapua-tekniikkaa voidaan käyttää eri toque-lajeissa. Tyypillisimmässä muodossaan alzapua sisältää kolmentyyppisiä, no- 
peasti toistettuja iskuja seuraavalla tavalla.

1. Peukalo soittaa alaspäisen näppäyksen aloittaen tietystä sointusävelestä. Tämä sävel kuuluu melodiaan ja se on soinnun tärkein sävel. Usein peukalonäppäykseen yhdistetään golpe.

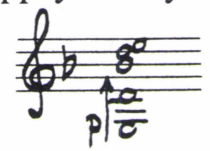

2. Peukalo soittaa saman soinnun ylöspäisellä iskulla, jolloin peukalon kynsi osuu kieliin. Tämä korostus antaa rytmille sen luonteenomaisen piirteen.

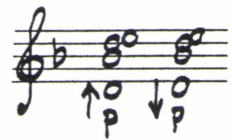

3. Peukalo soittaa kiinteällä apoyandonäppäyksellä (nk. tukinäppäys) melodiasävelen bassokielellä. (Martin 1978, 79)

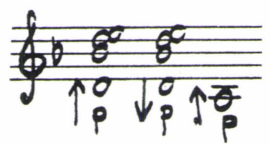

Vaikka alzapua on kehitetty viime vuosina virtuoositekniikaksi, sen alkuperä on luultavasti vanha, koska samanlaista tekniikkaa voidaan kuulla kitaran eteläisen serkun, $u d$-luutun soitossa. Peukalon käyttö ylöspäisenä iskuna oli aikaisemmin yleinen käytäntö - ei pelkästään rasqueo-jaksoissa, vaan myös yksittäisten sävelten soitossa. Nykyisin tekniikka on surkastunut pois yksittäisten sävelten soitossa, vaikkakin sitä voidaan kuulla joskus, erityisesti Moron de la Fronteran flamencoperinteessä. (ibid., 80) On oleellista,että peukalolla voidaan tuottaa selkeä ja painokas ääni, joka on hyvälle flamenconsoitolle luonteenomainen piirre (Batista 1972, 22).

Ligado. Tämä tekniikka on flamenconsoitossa samanlainen kuin klassisessa kitaransoitossa tavattava legato-tekniikka. Ylöspäinen legato soitetaan siten, että (oikean käden) näppäyksen jälkeen vasemman käden jokin sormi iskee kielen kiinni otenauhaan sen verran voimakkaasti, että erillistä oikean käden näppäystä ei tarvita äänen tuottamiseksi. Alaspäisessä ligadossa näpätään vasemman käden valmiiksi painamaa kieltä, minkä jälkeen kieli "nyhtäistään" alaspäin. Tämän vasemman käden liikkeen vaikutuksesta kieli alkaa värähdellä ilman oikean käden erillistä näppäystä.

Tekniikkana tämä on näppäilysoitinten osalta yleismaailmallinen ilmiö, ei siis spesifisti flamencotekniikka. Ligadotekniikassa on flamencossa kuitenkin erikoista yhdistämistapa, jossa oikean käden peukalolla soitetaan tiettyihin epäiskuisiin kohtiin aksentteja samalla kun vasen käsi soittaa 
pitkiä ligadosarjoja. (Esim. Pena 1976, 32).

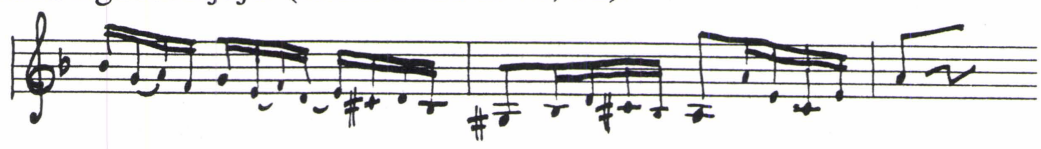

Tällä tavalla muodostuu pitkiä ornamenttisarjoja, jotka ovat tyylillisesti hyvin lähellä cante jondoa, mutta sen lisäksi ne muistuttavat erilaisten arabialaisten kielisoitinten ilmaisutapoja. (Esim. Tar -luuttu).

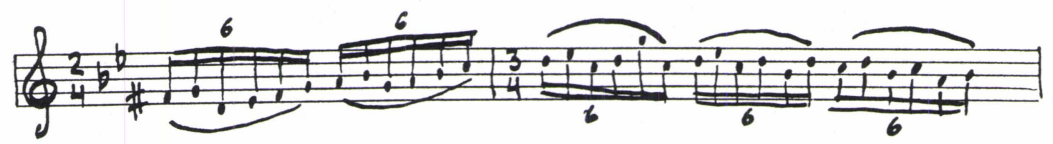

Improvisointi

Kitaransoiton sanotaan flamencossa olevan improvisoitua, koska kitaristi ei ennakolta ole rajoittunut määrättyyn rutiiniin tai kirjoitettuuun nuottiin. Hän on vapaa soittamaan mitä haluaa, mutta tämä ei tarkoita, että hän keksisi kaiken juuri soittaessaan. Improvisointi tapahtuu paremminkin valintojen kautta, kuin välittömiä uudistuksia keksimällä. Kitaristi valitsee falseta- ja rasqueo-jaksoja hallitsemastaan repertuaarista. (Martin 1978, 105) Nämä jaksot ovat suurelta osin stereotyyppisiä, ja samanlaiset jaksot ja melodiset aiheet toistuvat eri kitaristeilla lähes samanlaisina. Tällä tavalla flamenco on säilyttänyt eräänlaisen tyylillisen kiinteytensä. Ratkaisut ovat yksilöllisiä, mutta eri soittajien esityksistä on havaittavissa tyylillinen kollektiivisuus.

Esim.1. Pena, 12

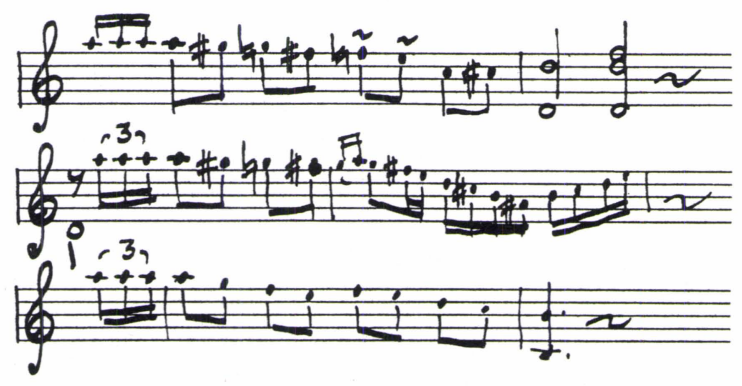

Esim. 3. Martin , 88

Pitkälti äänilevyjen vuoksi ovat tekniikan standardit korkeammat kuin koskaan ennen (Martin 1978, 71). Kokenut kitaristi tuntee soittamistaan falsetoista ja rasqueoista useita eri variantteja. Hän voi yhdistellä nämä jaksot eri tavalla, jotta ne parhaiten soveltuisivat tunnelmaan. Lopputuloksena on se, että kitaristi harvoin toistaa yhtään "toqueta" samanlaisena eri kerroilla. Sointulopukkeita voidaan lainata eri lajeista. Debla saatta esiin- 
tyä esim. martineten lopussa. (Salin, suullinen tieto) Joissakin tapauksissa kitaristi saattaa harjoitella hyvin huolellisesti tiettyjä jaksoja, mutta toisissa, vähemmän muodollisissa tilaisuuksissa hän soittaa "niinkuin tuntee". Hän on vapaa muuntelemaan valintojaan, kuitenkin muistaen sen, että hän aina huolehtii rytmistä, ja sen on palveltava laulajan ja tanssijan tarpeita (Martin 1978, 105).

Kitaristien luovuudessa ja soiton joustavuudessa on yksilöllisiä eroja. Uransa varhaisessa vaiheessa kitaristi kokoaa materiaalia imitoimalla ja omaksumalla musiikkia, jota hän kuulee toisilta soittajilta. Tämä tilanne on sama kuin kirjoittamattomissa kulttuureissa yleensä. Samalla tavalla tapahtuu suullisen perinteen välittyminen, yhtä hyvin kuin koko folkloren välittyminen. Tällä tavalla myös jazz-muusikot perehtyvät tyyleihin. Myöhemmin, jos kitaristilla on taipumusta säveltämiseen, hän saattaa kehittää omia variantteja.

Yhteisöllisyys on flamencossa perinteisesti ollut tärkeässä asemassa. Flamenco-tilaisuudet eli juergat ovat perinteisesti tapahtuneet suvun tai heimon sisäisenä tapahtumana, jolloin kyseessä ovat olleet häät, ristiäiset tai hautajaiset. (Quintana 1960, 210-213). Musiikkikulttuureissa, jotka eivät perustu kirjoitettuun nuottiin, perinteen välittyminen nojaa suulliseen traditioon. Perinne säilyy muistissa, ja siirtyy sukupolvelta toiselle tämän mekanismin välityksellä. Mikäli välittymistä ei tapahdu, perinne häviää. Tämän vuoksi kansanmusiikkikappaleen täytyy edustaa jollakin tavalla yhteisön musiikillista makua ja esteettistä mieltymystä, eikä niinkään ole kysymys yksilöllisen, yhteisöstä erkaantuneen säveltäjän luomuksesta (Nettl 1973, 4).

Tällä tavalla yhteisö tavallaan kontrolloi sävelmävarastoa; toiset hyväksytään, toisia ei. Jos kappaletta ei voida sinällään hyväksyä, se voidaan muuttaa sopimaan yhteisön musiikilliseen tyyliin. Tällaisesta esimerkkinä voi mainita flamencossa esiintyvät yhdistelmät eri musiikkilajeista. Vuosien mittaan muutokset pyrkivät tulemaan kappaleen integroituneiksi osiksi. Flamencossa esiintyy huomattava määrä fraaseja, jotka toistuvat eri kitaristeilla lähes samanlaisina. Tällöin nämä fraasit ovat läpäisseet "yhteisön musiikillisen seulan" ja kuuluvat siten elävään perinteeseen.

Vaikka musiikin luominen on yksilöllinen tapahtuma, monet esittäjät tekevät ajanmittaan muutoksia. Tällöin voidaan puhua "yhteisöllisestä uudelleenluomisesta".

Yksilöllisyys. Vaikka improvisaatio on yksilöllinen tapahtuma, vaikuttaa yhteisöllinen maku valinnanmahdollisuuksiin. Musiikissa on kui- 
tenkin aina ollut innovaattoreita, jotka vaikuttavat useisiin sukupolviin. Flamenco on kiinteä osa mustalaisten kulttuuria, joten innovaation on oltava merkittävä, jotta vaikutus tulisi osaksi musiikkityyliä, tai toisin sanottuna, jotta yhteisöllinen maku muuttuisi. Parhaimmat flamencotaiteilijat antavat nimensä jollekin kappaleluokalle, joten tavallaan se kansanmusiikin kriteeri, että tekijän on oltava tuntematon, ei täysin päde. Nykyajan tunnetuin flamencokitaristi Paco de Lucia (joka ei ole mustalainen) on vaikuttanut kehitykseen siten, että useimmat kitaristit soittavat hänen tyylillään. Sevillassa vuonna 1987 mustalaiset soittivat de Lucian kappaleita. Paco de Lucia on yhdistänyt tyylissään latinalais-amerikkalaisia ja jazz-vaikutteita, eikä se ole ollut kaikkien puritanistien mieleen. Toisaalta jotkut ammattilaiset sanovat hänestä: "Es ingenio". (Hän on nero).

Yksilöllisyys ei tapahdu flamencossa niinkään yksilöllisen improvisoinnin (tosin sitäkin esiintyy), kuin erilaisten, jo olemassa olevien varianttien esittämisellä, tai niiden hienovaraisella muuntelulla.

\section{Lajit}

Flamenco käsittää monia kappalelajeja. Useimmiten kitaristit keskittyvät muutamiin lajeihin, eivätkä yritäkään opetella kaikkia näistä. Koska nimiä on enemmän kuin varsinaisia lajeja, aiheuttaa tämä sekaannusta. Nimityksissä ei ole standardeja, vaan usein kappale saa jonkin lisämääreen esim. Granadinas tai Media Granadinas. Nimityksiä on niin paljon, etteivät perinteenkantajat tunnista kaikkia. Tässä työssä on esitetty tyypillisimmät lajit.

\section{Soleares}

Soleares on perusta, josta monet muut "toquet" ovat kehittyneet. Andalusiassa melkein jokainen kitaransoiton opiskelija aloittaa siitä. Soleares on luonteeltaan traaginen ja sen sanat käsittelevät usein lohduttomuutta ja kuolemaa. Solearesin compas eli rytmi käsittää 12 iskua, joiden painotukset jakautuvat seuraavasti (Martin 1978, 16).

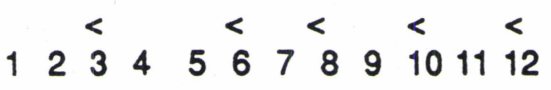


Solearesin kitarasäestys on seuraavanlainen.

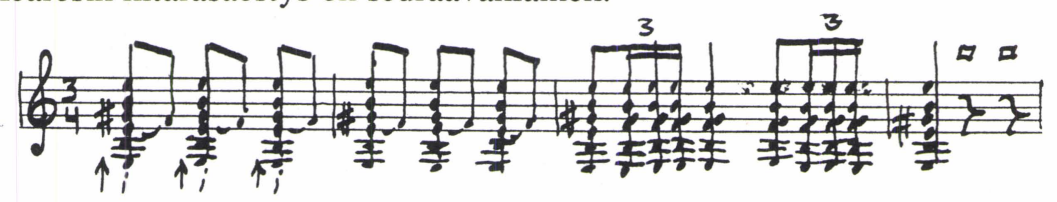

Esimerkin viimeisessä tahdissa esiintyvät kaksi golpea on merkitty neliöllä. Solearesin sävellajia pidetään fryygisenä (Martin 1978, 15). Tässä yhteydessä on kuitenkin huomattava korotettu kolmas aste. Edellisessä esimerkissä rytmi on merkitty 3/4-tahtilajiin, millä seikalla ei ole kovin paljon merkitystä flamemco-musiikiin suhteen, sillä painotukset jakautuvat eri tavalla kuin normaalisti länsimaisessa taidemusiikissa. Nämä painotukset on merkitty erikseen ja tahtiviivojen käyttö on vain konventio, joka helpottaaa nuottien seuraamista ( Martin 1978, 18 ).

Rasqueado-jaksoa seuraava compas palautuu takaisin säestyksen harmoniaan soolon aluksi. Painokasta jaksoa, jota kutsutaan nimellä llamada (kutsu), käytetään aloitusmerkkinä laululle tai tanssille, tai kuten tässä, melodialle. Tässä llamada-jakso perustuu E-duuri- ja F-suurseptimisoinnuille, joista jälkimmäinen soitetaan 3., 7. ja 9. iskulla. Llamadan kaksi viimeistä iskua ovat taukoa. Näille tauoille on annettava täysimittainen kesto, jotta rytmi jatkuisi oikealla tavalla.

Llamada

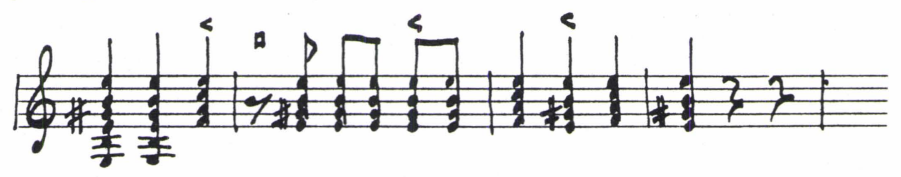

Falseta

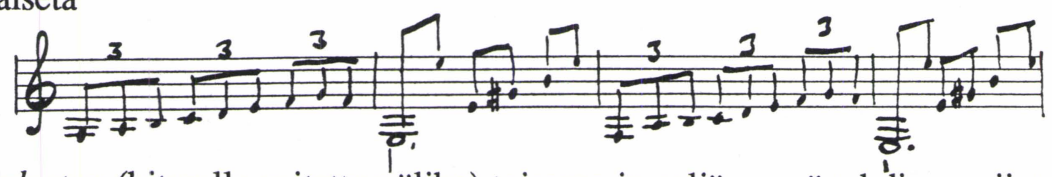

Falsetan (kitaralla soitettu välike) toisessa ja neljännessä tahdissa esiintyy murrettuna E-duurisointu, joka on päätösfraasina yleinen flamencossa. Tällaisen fraasin tehtävänä on täsmentää rytmi melodisen jakson tai rasqueado-jakson jälkeen. Falsetassa esiintyy flamencolle tyypillinen tekniikka, jossa melodiajakso soitetaan peukalolla. Falseta on tärkeässä asemassa flamenco-kitaransoitossa. Monet falsetat luodaan sointuotteiden pohjalta ( Martin 1978, 18 ).

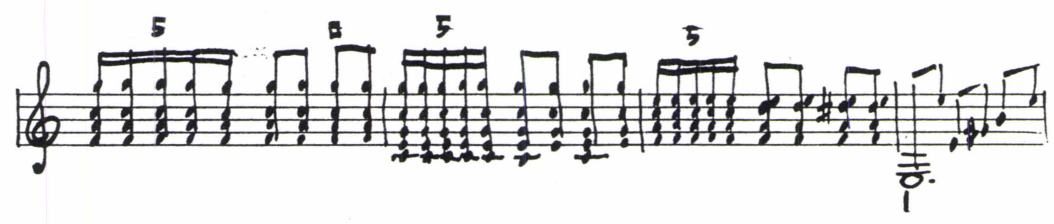


Seguiriyas. Tätä pidetään syvällisimpänä ja intohimoisimpana lajina flamenconsoitossa. Kuten soleares, tämänkin lajin alkuperä liittyy läheisesti Andalusian mustalaisiin. Seguiriyasia esitettiin laajemmin 1800-luvun jälkipuoliskolla, ja siitä kehittyi myöhemmin useita yksilöllisiä muotoja. Alunperin seguiriyaksessa ei ollut kitarasäestystä. Seguiriyaksen tanssiversio on suunniteltu teatteriesityksiä varten. "Cante por seguiriyasta" on kuvattu yksinäisen miehen kamppailuksi epäonnea ja kuolevaisuutta vastaan ( Martin 1978, 38 ).

Seguiriyaksen compasissa yhdistyvät tasa- ja kolmijakoiset iskualat. Koko säe on viisi-iskuinen. On muodostunut tavaksi nuotintaa rytmi käyttäen 3/4- ja 6/8-tahtilajeja.

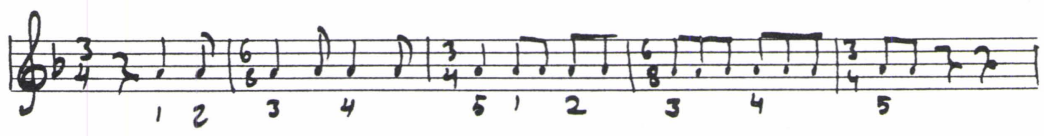

Tässä yhteydessä tahtiviivat eivät osoita painotusten sijoittumista, vaan niiden sijoittumista osoittavat numerot. Rytminen energia tähtää viiden-nelle iskulle, joka on fraasin viimeinen isku. Koska rytmi muodostuu 3/4- ja 6/8-tahtilajeista ja näissä kummassakin on perusyksikkö $1 / 8$, on kyseessä additiivinen rytmi, jotka ovat yleisiä panislamilaisessa kulttuuripiirissä. Seguiriyaksen rytmissä on vaikutelma yhdistetyistä harvennetuista ja tihennetyistä iskualoista. Tämä vaikutelma syntyy siitä, että parillisten iskualojen kahdeksasosaiskut yhdistetään neljäsosaiskuiksi, jolloin näiden neljäsosien kohdalla soitetaan golpe, tai pidetään tauko.

Seguiriyas soitetaan asemassa, josta käytetään termiä "por medio". Aloitussointu on tällöin A-duuri ja skaala on fryyginen (tai oikeammin sovellettu fryyginen). Toinen tärkeä sointu seguiriyaksessa on B-duuri, joka soitetaan käyttäen myös vapaata d-kieltä, jolloin sointu saa tietynlaisen sointivärin. Usein kertautuva välifraasi, jonka tehtävä on jäsentää rytmiä canten tai falsetojen välillä, on esimerkiksi seuraavanlainen (Martin 1978, 39-41).

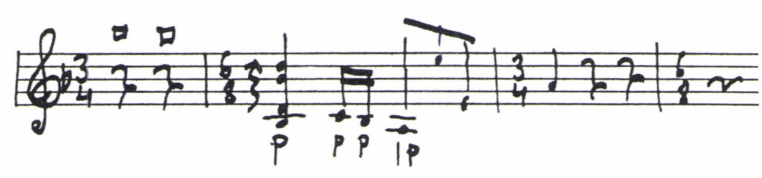

Alegrias

Alegria tarkoittaa iloa tai iloisuutta, jonka monikkomuoto alegrias on. Alegria kuuluu laajempaan toque-perheeseen, jota kutsutaan nimellä cantinas. Alegrias on omaksuttu flamencoon oletettavasti aragonialaisten me- 
rimiesten laulamista jota-lauluista. Jotan melodiat laitettiin solearesin rytmiin. Alegrias ei esiinny fryygisessä moodissa, vaan duurissa (joskus mollissa), mikä sopii hyvin yhteen tämän genren valoisan luonteen kanssa. Alegrias on usein A-duurissa. Alegriaksen compas on sama kuin solearesissa, ts. fraasissa on 12 iskua, joiden painotukset jakautuvat seuraavasti.

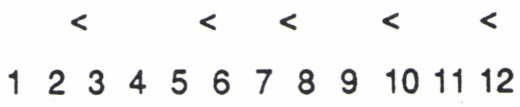

Nykyisin käytetään usein monimutkaista kontrarytmiä, jossa esiintyy synkooppeja. Soinnutus noudattaa eurooppalaisen tonaliteetin tehoja. Siinä käytetään I, IV ja V asteen funktioita.

Alegriaksessa esiintyy falseta-jakso, jonka pintarytmi muodostuu trioleista. Basso soitetaan peukalolla, joka on käden vahvin sormi. Tästä seuraa, että painotukset luonnostaan lankeavat näille sävelille. Näiden painotusten lisäksi falsetassa on pohjana alegriaksen compas. Tällöin muodostuu päällekkäisesti kaksi- ja kolmijakoisia rytmejä seuraavasti.

Esim. Pena, 20

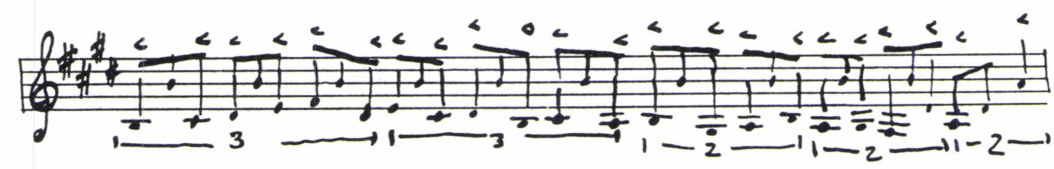

Pintatason rytmin yhdistäminen perusrytmiin luo musiikkiin voimakkaasti sykkivän jännitteen. Asteikossa esiintyvä dis ${ }^{1}$-sävel on e-mollissa johtosävel, mutta tässä yhteydessä se ei esiinny johtosävelfunktiossa, jolloin sen kuuluisi purkautua ylöspäin. Asteikkoon muodostuu pieniä ja ylinousevia sekunteja.

\section{Fandangos}

Fandango on arabialaisperäinen sana, ja 1300-luvulta alkaen on erilaisia fandangoja tunnettu kaikkialla Espanjassa ja klassisista säveltäjistä on mm. Mozart noteerannut sen (Howson 1965, 263). Andalusiasta tämä muinainen tanssi- ja laulumuoto levisi läpi koko Espanjan. Andalusiassa nämä fandangot on adoptoitu osaksi flamencoa.

Pohjoisessa se antoi perustan jotalle, kun taas etelässä se oli perusta rondenalle, malaguenalle, granadinalle, tarantalle, mineralle ja cartageneralle. Fandangot olivat tämän vuosisadan alussa niin suosittuja, että tämä laji jätti lähes varjoonsa muut lajit.

Nykyään voimme kitaristin näkökulmasta katsottuna puhua kahdesta fandangon päätyypistä. Toisaalta on olemassa voimakkaaasti ekspressiivi- 
nen Fandangos grandes -luokka, mikä kuuluu pääasiallisesti lauluun. Tämä laji sallii huomattavan vapauden compasin suhteen. Toisaalta on olemassa voimakkaasti rytmisiä fandangoja, joita voidaan sekä tanssia, että laulaa. Nämä yhdistetään erityisesti Huelvan provinssiin ja kaupunkiin ( id ).

\section{Fandangos de Huelva}

Rytmi on tässä lajissa eloisa ja painokas. Sen rytminen rakenne vaikuttaa yksinkertaiselta ja suoralta. Kuitenkin moni kitaransoiton opiskelija huomaa sen yhdeksi vaikeimmista lajeista. Tämän lajin erikoisuutena on falsetojen suhde väliintuleviin rytmisiin rasgueoihin. Perustaltaan compas on 12-iskuinen. Toisin kuin solearesissa, jossa aksentit sijoittuvat samoille tahdinosille, fandangossa compas ei käyttäydy näin yksinkertaisesti. Voi olla hämmentävää numeroida iskut aksenttien osalta, koska rasgueo- ja falseta-jaksot on laskettava eri tavoin. Monissa falsetoissa on 14 iskua päätösfraasissa. Nämä falsetat alkavat kaksi iskua aikaisemmin, kuin odottaisi. $\mathrm{Ne}$ falsetat, jotka perustuvat laulun coplasiin, noudattavat paremmin 12iskuista jaksoa. Niissä ei ole tarvetta pidempään päätökseen eikä aikaisempaan aloitukseen (Martin 1978, 60-61).

Fandangon compas voitaisiin laskea iskuina 1-12. Rasgueon rytmi sopisi hyvin tähän metodiin, mutta huomaamme että yleisin falseta-tyyppi, jota kutsumme I tyypin falsetaksi, alkaa iskulla numero 11, jolla on aksentti. Mieluummin kuin laskisi 11,12,1,2 jne, on paljon yksinkertaisempaa laskea compas 1-12 silloin kun fraasit ovat 6 iskua pitkiä. Tehdäksemme tämän, meidän on laskettava falsetaa edeltävä rasgueo-compas vain 110, jotta voisimme aloittaa laskemaan 1-12 falsetan alussa.

Mutta miksi ennen falsetaa esiintyvä rasgueo compas täytyy olla kaksi iskua lyhyempi kuin muut rasgueo compasit. Vastaus on näiden falsetojen päätöksessä, jossa esiintyvä compas lasketaan 1-14. Yhteenvetona laskutavasta voimme esittää seuraavaa.

I Tyypin falseta

$\begin{array}{lllll}\begin{array}{l}\text { rytminen } \\ \text { rasgueo }\end{array} & \begin{array}{l}1 \text { lyhyt compas } \\ \text { ennen falsetaa }\end{array} & \begin{array}{l}\text { I-tyypin falseta } \\ \text { fraasit 6-iskuisia }\end{array} & \begin{array}{l}\text { falsetan } \\ \text { pääös }\end{array} & \begin{array}{l}\text { rytminen } \\ \text { rasgueo }\end{array} \\ 1-12 & 1-10 & 1-12 & 1-14 & 1-12\end{array}$

Niitä falsetoja, jotka ovat coplasin (runofraasit) melodioita, voimme kutsua II tyyypin falsetoiksi. Näitä on kitaristien repertuaarissa vähemmän kuin I tyypin falsetoja, ja ne ovat helpommin laskettavia. Näiden melodioiden fraasit ovat 12-iskuisia (niissä ei ole laajennettua 14-iskuista päätös- 
compasia). Laskeminen on näinollen suoraviivaista ja voidaan esittää seuraavasti.

II Tyypin falseta

$\begin{array}{llll}\begin{array}{l}\text { rytminen } \\ \text { rasgueo- }\end{array} & \begin{array}{l}\text { II } \\ \text { tyypin } \\ \text { compas }\end{array} & \begin{array}{l}\text { rytminen } \\ \text { rasgueo- }\end{array} & \text { etc. } \\ 1-12 & 1-12 & 1-12 & \\ & & \end{array}$

Fandangos de Huelvan falseta on huomattavan itämainen sävyltään, mikä johtuu suurelta osin siitä, että falsetassa painotetaan ja toistetaan korotettua III astetta, jolloin karakteristinen ylinouseva sekunti korostuu.

Esim. Martin, 62

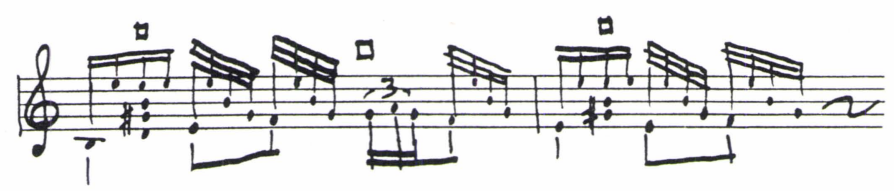

Sevillanas

Huolimatta nimestään, sevillanas ei ole lähtöisin Sevillasta. Se on eriytynyt castilialaisesta kansantanssista, jonka nimi on seguidilla. Sevillanasit ovat erittäin suosittuja koko Andalusiassa, missä niitä tanssitaan pääasiallisesti festivaaleissa, erityisesti kuuluisassa Sevillan feria-juhlassa. Sevillanas on iloinen, värikäs paritanssi, jossa säestyksenä kitaran ohella on laulu ja kastanjettien soitto (Pena 1976, 11).

Sevillanasin luonne on rehevä ja täynnä iloa ja runollista suuruutta, mutta jotkut melodiat ovat paljon vakavamman sävyisiä. Ne melodiat, jotka ovat fryygisessä moodissa ovat tyypillisesti flamenco-luonteisia, mutta useimmiten melodiat ovat duurissa tai mollissa, jolloin ne muistuttavat läheisesti muuta espanjalaista kansanmusiikkia. Rytmi on tavallisesti reipas, mutta voi olla myös rauhallinen joissakin vakavissa coplaseissa (Martin 1978,66 ).

Sevillanasissa on aluksi rasqueo-jakso, jota seuraa salida - lyhyt melodian esittelyjakso. Jos laulaja on mukana, hän aloittaa tästä. Rasqueo-jakso yhdistää salidan edelleen ns. coplaan, jossa vaiheessa tanssija voi tulla mukaan. Copla päättyy usein salida-jaksoon. Copla toistetaan kolme kertaa - joko variaatioiden kanssa tai ilman. Coplas-jaksot vaihtelevat melodian ja sävellajin suhteen, mutta rytmi säilyy muuttumattomana (Pena 1976, $11)$. 
Sevillanasin compas. Compas noudattaa tässä lajissa tiukkaa muotoa. Rytmiä on vaikea omaksua sanoin selittämallä tai nuottien pohjalta. Samoin kuin Fandangos de Huelvan tapauksessa, jota sevillanas muistuttaa, transkriptiot ovat usein heikosti tehtyjä. Jälleen 3/4-tahtilaji on omaksuttu selvimmäksi tavaksi ilmaista rytmi niinkuin se on elävässä musiikissa painotettu. Mutta kuten kaikessa flamenco-musiikissa, on tärkeää olla sitoutumatta tahtiviivoihin: elävä rytminen pulssi on ratkaiseva tekijä. Sevillanasilla on karakteristinen rakenne, joka voidaan ilmaista seuraavalla tavalla ( Martin 1978, 66 ):

rytminen esittely salida rytmi: melodia soitetaan 3 kertaa

Ensin kitara soittaa rytmisen esittelyn, jonka kesto lasketaan kuuteen. Tämä tavallisesti käsittää rasgueoita sekä ylös- ja alaslyöntejä, mutta voi myös sisältää näpättyjä sointuja ja arpeggioita. Seuraavaksi esiintyy salida (kirjallisesti lähtö), joka on lyhyt melodian esittelyjakso. Huomaamme, että tämä on sama tai lähes sama kuin viimeinen osa melodiaa (copla). Salidaa seuraavan rytmisen jakson jälkeen täysi melodia soitetaan kolme kertaa. Usein kolmannella kerralla mukaan sisällytetään variaatioita. Kappale loppuu yhtäkkisesti. Tätä seuraa lyhyt tauko, ja sen jälkeen kitaristi aloittaa uuden sevillanasin, joka useassa tapauksessa on eri sävellajissa. Yleisesti soitetaan neljä erilaista sevillanasia peräkkäin.

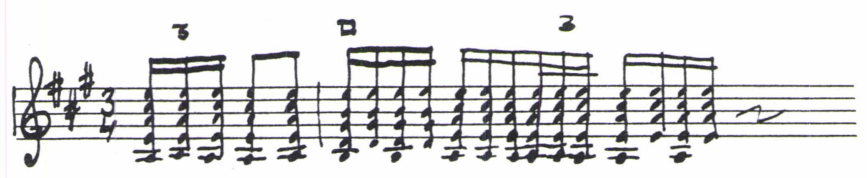

Esim. Martin, 67

Sevillanasin compas lasketaan koko ajan kuuteen, mutta tässäkin tapauksessa on unohdettava tahtiviivojen mekitys. Nuottikirjoituksessa laskeminen aloitetaan itseasiassa tahdin toiselta osalta.

Erikoisuutena Sevillanasin rytmin käsittelyssä on, että rasqueo-, salida- ja coplas-jaksot voivat olla erimittaisia eri esittäjillä. Juan Martin soittaa rasqueo-jaksot kolmetahtisina ja Paco Pena 6-tahtisina. Coplan Martin soittaa kuusitahtisina ja Pena 12-tahtisena. Salida-jaksot ovat molemmilla kolme tahtia. Andres Batista soittaa rasqueon kolme-tahtisena, salidan kolme-tahtisena ja coplan 12-tahtisena. Emilio Medinalla on myös oma tapansa käsitellä jaksoja. Yhteenvetona voi esittää seuraavan: 


$\begin{array}{llll} & \text { rasqueo } & \text { salida } & \text { copla ( kaikilla 3 kertaa ) } \\ \text { Martin, 67-69 } & 3 & 3 & 6 \\ \text { Pena, 75-77 } & 6 & 3 & 12 \\ \text { Batista, 111,112 } & 3 & 3 & 12 \\ \text { Medina, } 116 & 5 & 6 & 12 \text { ( III kerralla 10) }\end{array}$

\section{Bulerias}

Voimakas syke ja tukeva pulssi tekevät buleriaksesta mitä mielenkiintoisimman lajin, joka voi olla suuri haaste kitaristille ja mitä häikäisevin taidonnäyte. Bulerias onkin flamencon lajina keskeinen ja ilmaisumahdollisuuksiltaan moninainen. Tämän lajin tukeva, sykkivä energia olisi omaksuttava mahdollisimman varhain osaksi soittoa. Bulerias on tärkeä koko kitaransoiton päämäärän kannalta. Flamencon rytminen jännittävyys ei pääasiallisesti johdu nopeudesta, vaan peruspulssista ja compasin aksenteista. Opettelemalla soittamaan bulerias hyvin hitaasti, oppii keskittymään rytmiin ja sen ylläpitämiseen sekä rasqueon että falsetan aikana. ( Martin 1978, 74 ).

Buleriaksen historiallinen kehitys. Sana "buleria" näyttää olevan mustalaismuunnos sanasta "burleria", joka tarkoittaa ivaa. Se näyttää olevan uusi cante gitanosta kehittynyt muoto, joka tuskin on sata vuotta vanhempi. Tyylit ovat muuttuneet ja muuttuvat koko ajan. Buleriakset ovat toque-laji, joka on hyvin joustava. Tätä genreä on kutsuttu sanalla kaikkiruokainen, koska suuri joukko teemoja, mukaanlukien pop-lauluja ja eiespanjalaisia lauluja on istutettu buleriaksen compasiin. Monet tanssit, erityisesti soleares ja alegrias huipentuvat lopuksi buleriakseen.

Varhaisemmat buleriaksen tyypit olivat hyvin hitaita ja niitä kutsuttiin nimellä bulerias al golpe koska niille olivat luonteenomaisia voimakkaasti korostetut aksentit. Nopeita buleriaksia kutsuttiin nimellä bulerias ligadas niiden sujuvan ja vähemmän katkonaisen rytmin vuoksi. Ne ovat tulleet suosituiksi iloisen ja humoristisen laulutyylinsä vuoksi. Kitaratyyli on usein virtuoosimainen. Tähän päivään mennessä buleriaksen tyyli on muuttunut paljon, ja jopa viimeisen vuosikymmenen aikana on havaittavissa merkittäviä muutoksia. Compasiin on tullut uusia rasqueoja ja monimutkaisia synkoopppeja ja vastarytmejä sekä harmonioita, jotka ovat peräisin jazz-vaikutteisesta populaarimusiikista (Martin 1978,75).

Buleriaksen compas. Buleriaksen peruscompas noudattaa samaa muotoa kuin soleareksen compas. Se muodostuu 12-ìskuisesta jaksosta, jossa 
aksentit ovat 3., 6., 8., 10. ja 12. iskulla. Rytminen monimutkaisuus perustuu paljolti siihen, että yleisen 12-iskuisen jakson sisällä on toinen sisäinen 6-iskuinen rytmi, sekä synkooppeihin ja aksentteihin variaatioineen. Falsetojen korrekti ajoitus on tärkeä. Monet falsetat alkavat ensimmäisellä iskulla, mutta on monia muita falsetoja, jotka alkavat rasqueojakson viimeisen (10.) iskun jälkeen. Jotkut falsetat alkavat 10., jotkut 11. iskulla.

Falsetat vaihtelevat pituudeltaan. Melodiset fraasit voidaan laskea 6-iskuisina. Melodia voi kestää parillisen tai parittoman jakson 6-iskuisia fraaseja. Kuitenkin yleinen 12-iskuinen kehys säilyy. Selitys löytyy falsetan lopussa esiintyvistä rasqueo-iskuista. Jos sekvenssi lasketaan yhdestä kuuteen, falsetan viimeinen nuotti lankeaa tavallisesti neljännelle iskulle. Siellä missä falsetassa on parillinen joukko 6-iskuisia fraaseja, esiintyy 8-iskuinen säe ennenkuin seuraava 12-iskuinen säe alkaa. Siellä missä on pariton joukko 6-iskuisia fraaseja, tarvitaan pidemmän tyyppinen rasqueo-lopetus.

Hyvin usein falseta on koostunut pienistä fraaseista, joita seuraa pitkä fraasi. Jos jokin fraasi osuu parittomaan 6-iskuisten jaksoon (esim. falseta alkaa 12. iskulta ja päättyy 1. iskulle), silloin tarvitaan pitkä rasqueo-tyyppi "täydennykseksi" ennenkuin seuraava jakso alkaa täytenä. Tällä tavoin säännönmukainen 12-iskuinen compas säilyy.

Palmas eli kättentaputus toimii buleriaksessa oleellisena johtolankana sen ymmärtämiselle, miten 12-iskuinen compas toimii. Tämä voidaan laskea myös 6-iskuisen säkeenä, jossa iskut ovat 1., 2., 4. ja 5. iskulla. Sama rytmi voidaan kuulla kitaran golpeina, ja sitä voidaan korostaa joissakin raqueo- ja falseta-tyypeissä. Yhdistämällä 6-iskuinen ja 12-iskuinen rytmi saamme seuraavan yhdistelmän.

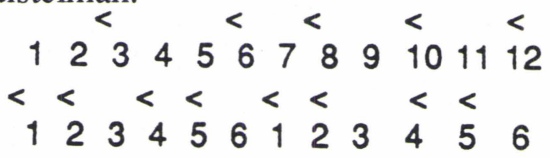

Kuten soleareksessa ja alegriaksessa, buleriaksen päätössointu on 10. tahdinosalla.

Vastarytmi eli "contratiempo". Compas, jossa on 12 iskua yhdessä 6iskuisen sisäisen rytmin kanssa luovat buleriaksen rytmisen perustan. Buleriasta ensi kertaa kuunnellessa tämä laji kuulostaa hyvin monimutkaiselta lisäsynkooppiensa ansiosta. Näitä voi kitaristi luoda rasqueoissaan ja falsetoissaan yhtä hyvin kuin tanssija jalkatyöskentelyssään tai kättentaputuksissaan. Edellä esitettyihin rytmeihin voidaan lisätä puoli-iskuja. Bulerias on usein A-duuri-positiossa, josta käytetään ilmausta "por me- 
dio". Sävellaji on "sovellettu" a-fryyginen. Enimmäkseen soinnut ovat samat kuin seguiriyaksessa. Bulerias voidaan soittaa myös muissa sävellajeissa, kuten duurissa ja mollissa, yhtä hyvin kuin e-fryygisessä tai jopa fis-fryygisessä sävellajissa, joista viimeksi mainittu on uusi innovaatio (Martin 1978, 76).

\section{Farruca}

Ihmisiä, jotka tulivat Asturiaksen ja Galician maakunnista, kutsuttiin nimellä farrucos. Flamenco-farrucat tulivat esiin Gadizissa ilmeisesti pohjoisten asukkaiden tuomina. Vaikka laulua esitetään vielä nykyäänkin, on tämä laji pääasiallisesti tanssimusiikin ja kitaramusiikin muoto. Tämä ei ole syvämielinen laji, mutta se on puoleensavetävä kitarakappale. Soinnut soitetaan a-molli -positiosta, mutta joskus myös muista asemista. Myös fryygisen moodin jaksoja saattaa esiintyä.

\section{Compas ja aire}

Tämän lajin rytmin luonne on viriili ja painokas. Nuotinnoksessa käytetään usein 4/4-tahtilajia. Temponmuutokset seuraavat tanssissa tapahtuvia muutoksia. Miehen tanssissa, joka on dramaattinen ja korostetun maskuliininen, on viittauksia "corridaan" asentojen osalta. A-molli -sävellaji yhdessä 4/4-tahtilajin kanssa tekevät farrucasta yhden yksinkertaisimmista flamencolajeista kitaristille. Falsetassa käytetään picadoa, peukaloapoyandoa, oktaavaja ja tremoloa. Rasqueo-esittely alkaa perinteisellä sointusekvenssillä E-septimisoinnun puitteissa, jossa 2. kielellä soitetaan sävelkuvio h, cis, d ja h, jonka jälkeen harmonia purkautuu a-molliin ja etenee siitä d-molliin. Tämä jakso sisältää neljä tahtia, joista kaksi ensimmäistä kerrataan sellaisenaan.

\section{4/4 |: E7 I Am :| Dm I Am I etc.}

\section{Granadinas}

Granadinas tai, kuten flamencon esittäjät sanovat granainas, on eräs laji fandango grandesta, joka puolestaan on peräisin vanhasta Granadan kaupungista. Laulussa on kuultavissa rikkaasti koristeltu orientaalinen sävy, mikä piirre on peräisin ajalta jolloin Granada oli maurilaisvallan 
alaisuudessa vuosina 711-1492. Koristelussa käytetään tremolo- ja ligadotekniikoita. Tyypillinen aloitusfraasi on seuravaanlainen ( Martin 1978, 100 ; Medina 1977, 75 ):

Martin

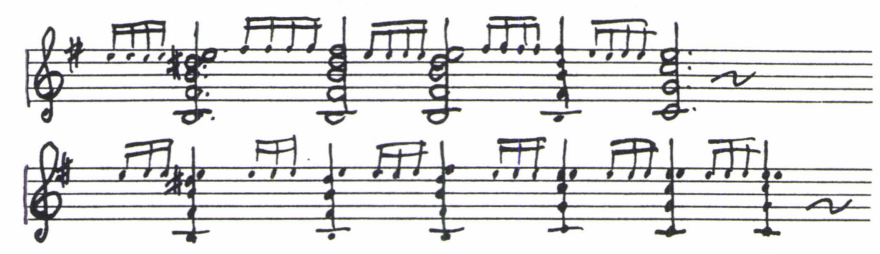

Medina

Suuri osa tämän lajin musiikista soitetaan vapaassa tempossa (en toque libre), mikä antaa esittäjälle paljon vapautta persoonalliseen ilmaisuun ja tempon käsitelyyn. Kuten fandangos grandes -lajissa, on tässäkin osia, jotka ovat säännöllisessä rytmissä. Molemmissa näissä lajeissa on 6-iskuisia rytmisiä jaksoja. Moodi perustuu h-fryygiselle asteikolle, jossa on korotettu III aste.

\section{Tientos}

Tientosin suoraluonteiselle rytmille ovat ominaisia myös korostukset ja synkoopit. Perinteinen tapa opetella rytmi on imitoida ja laskea rytmi ääneen, paremminkin kuin opetella nuoteista. Tientosin perusrytmi voidaan kuvata seuraavalla tavalla, jossa kertautuu 4-iskuinen säe.

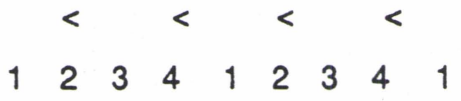

Iskutus osuu 2. ja 4. iskulle. Tästä syystä ja sointujen ajoituksen vuoksi tahtiviivat sijoittuvat 1 . ja 2 . iskun väliin. Tientosin rytmin modifikaatiossa iskut jaetaan kolmeeen osaan, jolloin nuotinnoksessa käytetään 12/8tahtilajia 4/4-tahtilajin sijasta. Tällöin jokaista 4/4-tahtilajin iskua vastaa 12/8-tahtilajissa pisteellinen rytmi.

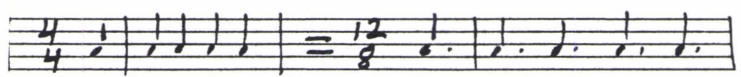

Toisessa modifikaatiossa esiintyy synkooppi jokaisen tahdin ensimmäisellä puoliskolla. 12/8-tahtilajin ensimmäiset iskut ( raavalla rytmillä ( ( $\bar{y}$ ). Tientosin perusrytmi esitetään siten seuraavasti. (Martin 1978, 106-107):

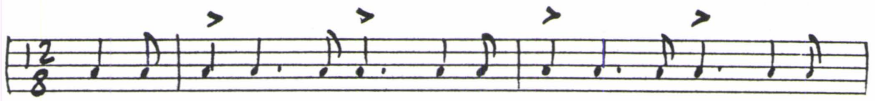


Nuotinnos on yhdistetyssä 2/4- ja 6/8-tahtilajissa. Tässä tapauksessa jokainen tahti on jaettu kahteen samankestoiseen puoliskoon. Nämä osat ovat jaettavissa kahteen (2/4) tai kolmeen (6/8) osaan. Tientos tavallisesti loppuu nopeampaan jaksoon rytmissä, joka on läheisesti sukua tangos flamencos-lajille. Yleensä tangos on nopeampi ja eloisampi kuin tientos, ja se on rytmisesti suoraviivaisempi (Pena 1976, 11).

Tientos poikkeaa muista flamencolajeista siinä suhteessa, että rytmin perusyksikköjä ei voida laskea suoraan yhteen, koska ne ovat erimittaisia. Nuotinnoksessa paljastuu flamencomusiikille ominainen piirre. Koska musiikin välitttyminen tapahtuu korvakuulolta, ei myöskään yhtenäistä käytäntöä nuotinnoksen suhteen ole olemassa. Juan Martinilla rytmi on 12/8, Paco Penalla 2/4 + 6/8 ja Emilio Medinalla 2/4

\section{Zapateado}

Zapateado (so. kengällä taputettu) on yleinen termi tanssin jalkatyöskentelylle, jossa käytetään kengän kärkeä (punta) ja kantapäätä (tacon). Tämä nimitys tarkoittaa myös erityistä miesten virtuoottista tanssia. Tämä tanssi soitetaan tanguillon rytmissä, joka on 6/8-tahtilajissa tai toisinaan 2/4tahtilajissa, jossa on trioleja. Toque on usein sävellajissa, joka vastaa Cpositiota.

Compas on ankaran säännöllinen. Se on tässä nuotinnettu rasqueo-jaksoissa 2/4-tahtilajiin ja falseta-jaksoissa 6/8- tahtilajiin. Tempossa esiintyy vaihteluita, jotka vastaavat tanssin eri variaatioita. Joissakin jaksoissa esiintyy jaksoja muunnosmollissa ja modulaatioita toisiinkin sävellajeihin (Martin 1978,11)

\section{Soleà por medio}

Soleà por medio, kuten myös soleà por bulerias on laji, joka on eriytynyt soleasta. Tällä lajilla on yhtäläisyyksiä varhaisiin buleriaksen tyyleihin. Tämä laji soitetaan positiosta, joka vastaa sointuotteeltaan A-duuria. Positiota kutsutaan nimellä "por medio". Tempo tässä lajissa on soleareksen ja modernin buleriaksen välillä. Soolo soitetaan tässä mustalaistyylillä, ja siinä esiintyy voimakkaita rasqueo-jaksoja falsetojen välillä. Se sisältää esimerkkejä 3-jakoisesta alzapua-tekniikasta sekä arpeggiotekniikasta. 


\section{Malaguenas}

Malagassa on fandango kehittynyt moniksi malaguenan tyyleiksi, joiden runosäkeet vaihtelevat tunnelmaltaan syvästä tragediasta huolettomaan huumoriin. Malaguenan on sen vuoksi katsottu edustavan "cante intermedio" -luokkaa, joka tarkoittaa tyylillistä keskiväliä. Nykypäivänä esitettävät laulut ovat peräisin viime vuosisadan lopulta. Niiden kehittyminen yksinkertaisista verdiales-melodioista voidaan liittää useisiin malaguenan esittäjiin. Erityisen kuuluisia esittäjiä ovat olleet Antonio Ortega, Enrique Jimenez ja Don Antonio Chacon.

Kun malaguenat kehittyivät, muuttui rytmi vapaammaksi ja melodiat kehittyivät taidokkaasti ornamentoiduiksi. Nykypäivän malaguena-muodoissa rytmi on osaksi vapaa (en toque libre) ja osaksi säännöllisessä 3/4rytmissä. Tässä lajissa on monia fandangon piirteitä. Musiikki perustuu Epositiolle ja asteikko on sovellettu fryyginen (Martin 1978, 120).

\section{Tarantos}

Almerian provinssin asukkaita on yleisesti kutsuttu nimellä tarantos. Taranto on voimakkaasti rytminen tyyli. Se on sukua tarantalle, muodolle joka on fandango granden alalaji. Taranta on peräisin Almeriasta. Tarantat ovat vapaita rytmiltään, mutta tarantot ovat ankaran säännönmukaisia ja painokkaita, ja niiden rytmi on joko 2/4- tai 4/4-tahtilajeissa. Tarantat ja tarantot ovat sävyltään hyvin orientaalisia, mikä johtuu niiden harmoniasta ja koristelusta. Tarantot ja tarantat ovat kaikissa muissa suhteissa, paitsi rytmissä samanlaisia ( Pena, 10 ). Sävellaji on fis-positiolle perustuva "sovellettu" fryyginen moodi. Sävy on hyvin dissonoiva, koska perussoinnussa soitetaan bassokielillä fis-, cis1- ja fis1-sävelet diskanttikielten säveliä g1-, h1- ja e2-säveliä vastaan. ( Martin 1978,124 )

Tarantassa säänöllisen rytmin puuttuminen aiheuttaa vaikeuksia nuotinnoksen kannalta ja nuoteille annetaankin likimääräiset arvot. Nuotinnos saatetaan tehdä ilman tahtiviivoja. Tarantassa ja tarantossa esiintyy eri kitaristeilla tyypillinen ligado-jakso. 
Martin, 125

Medina, 94

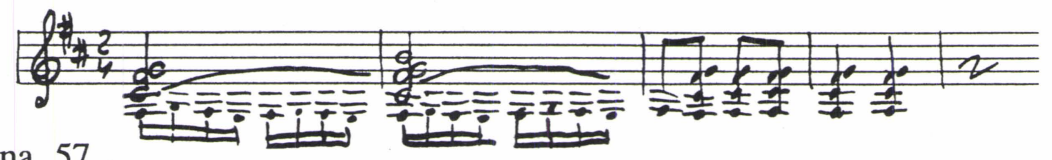

Pena, 57
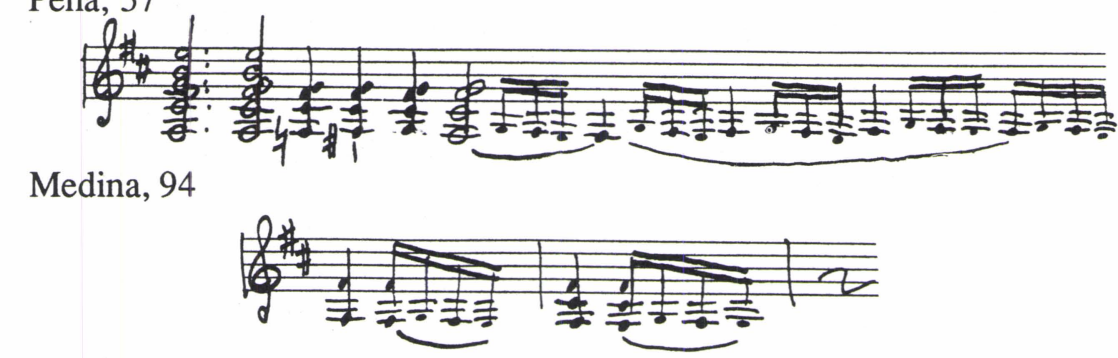

Rumba gitana

Tämä nykyaikainen ja populaari laji on esimerkki flamencon jatkuvasta muuttumisesta ja kehittymisestä. Rumba gitana heijastaa nykypäivän ideoita ja osoittaa voimakkaita latinalais-amerikkalaisia vaikutteita. Kuitenkin tämä laji on kiinteästi osa flamencoa. Se on kehittynyt tientoksesta ja tangosta. Sillä on synkopoitu rytmi. De Lucia: Entre dos aquas.

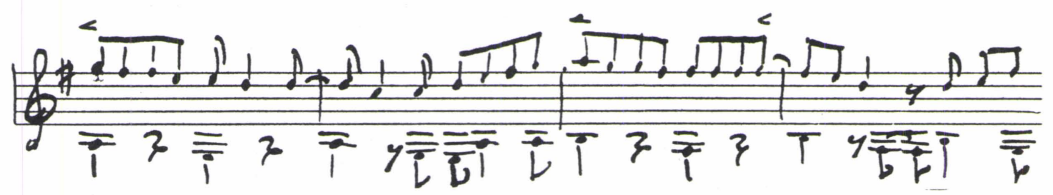

\section{Lähteet}

Batista, Andres

1972 Metodo de Guitarra flamenca. Union musical espanola. Madrid.

Davies, Ian.

1985 "Flamenco workshop." Guitar international. October Issue Vol. 14, No. 3. (Dorset, England).

Howson, Gerald.

1965 The flamencos of the Cadiz Bay. Hutchinson of London. Lucia, Paco de.

1965 Lo mejor de Paco de Lucia. Ediciones musicales Fontana S.A. Madrid.

Martin, Juan.

1978 El arte flamenco de la quitarra.United Music Publishers. London. 
Medina, Emilio.

1977 Metodo de quitarra flamenca. 12 edicion. Ricordi Americana. Buenos Aires.

Nettl, Bruno.

1973 Folk and traditional music of the Western continents. Second edition. Prentice-Hall, Inc.Englewood Cliffs, New Jersey.

Pena, Paco.

1976 Toques flamencos. Musical new services Ltd. Dorset. Plata, Manitas de.

1979 Flamenco guitar. Halstan \& Co. Limited, Amersham, Bucks. Pohren, Donn E.

1972 The Art of Flamenco. 3rd edition. Artes Graficas Luiz Perez, San Bernando, 82, Madrid-8.

Quintana, Bertha B.

1960 The deep song of the andalucian gypsies. New York.

\section{Haastattelut}

Ari Salin, s. 1945. Harrastanut flamencoa vuodesta 1960. Haastattelu Tapiolassa 22.2.1986 